\title{
Review
}

\section{Zinc Status in the Soils of Karnataka and Response of Horticultural Crops to Zinc Application : A Meta-analysis}

\author{
Ganeshamurthy A.N.*, Rajendiran S., Kalaivanan D. and Rupa T.R. \\ Division of Soil Science and Agricultural Chemistry \\ ICAR-Indian Institute of Horticultural Research \\ * Corresponding author, Email:angmurthy@gmail.com
}

\begin{abstract}
Zinc is considered as the fourth important yield limiting nutrient in India, after $\mathbf{N}, \mathbf{P}$, and K. From the regular soil analysis data, Indian soils $(50 \%)$ are found to be deficient in $\mathrm{Zn}$ and the zinc deficiency is likely to increase in future. Areas with low soil available $\mathrm{Zn}$ are often regions with widespread zinc deficiency in humans. Zinc malnutrition and deficiency in human is alarming and is gaining attention in recent years. Application of zinc to soil and crops is one of the simple and easiest ways to mitigate or alleviate $\mathrm{Zn}$ deficiency in human. Moreover $\mathrm{Zn}$ uptake, its translocation and yield response of various crops to applied $\mathrm{Zn}$ are need to be focused for finding sustainable solutions to the problem of zinc deficiency in crops and humans. In this manuscript, importance of $\mathrm{Zn}$ to plants and human, $\mathrm{Zn}$ malnutrition problems in India and global level, soil $\mathrm{Zn}$ status of Karnataka, various factors that responsible for $\mathrm{Zn}$ deficiency in the soils of Karnataka and the response of various horticultural crops to $\mathrm{Zn}$ application in the region is discussed. Soil maps are believed to be an important tool to delineate and manage nutrient deficient areas. It also elaborates the effective $\mathrm{Zn}$ management strategies to improve crop productivity and farm income.
\end{abstract}

Keywords: Crop production, Crop quality, Karnataka, Horticultural crops, Zinc deficiency, Zn management

\section{INTRODUCTION}

Zinc is one of the essential nutrients for plant growth and development. Though it is required in small quantity, it is crucial for plant development. In plants, $\mathrm{Zn}$ is a key constituent of many enzymes and proteins and plays a major role in wide range of processes such as growth hormone production and internode elongation. Zinc is absorbed by the plant through roots mostly in divalent ionic form $\left(\mathrm{Zn}^{2+}\right)$ from the soil solution. The primary source of $\mathrm{Zn}$ in soil is chemical and physical weathering of parent rocks and minerals. Mean soil $\mathrm{Zn}$ concentrations $\left([\mathrm{Zn}]_{\text {soi }}\right.$ ) varied from 50 and $66 \mu \mathrm{g}$ of total $\mathrm{Zn} \mathrm{g}^{-1}$ soil are typical for mineral and organic soils, respectively, with most agricultural soils containing 10 to $300 \mu \mathrm{g} \mathrm{Zn} \mathrm{g}^{-1}$ (Alloway, 1995). Secondary inputs of $\mathrm{Zn}$ to soils arise because of atmospheric (e.g. volcanoes, forest fires, and surface dusts) and biotic (e.g. decomposition, leaching/washoff from leaf surfaces) processes (Friedland, 1990). Further anthropogenic emission of $\mathrm{Zn}$ inputs to soil has increased due to industrial revolutions and resulted in buildup of $\mathrm{Zn}$ in soil particularly as a result of mining and smelting activities (Nriagu, 1996). The ratio of $\mathrm{Zn}$ emissions arising from anthropogenic and natural inputs is estimated to be $>20: 1$ (Friedland, 1990). However this is much localized and area specific accumulation that leads to $\mathrm{Zn}$ contamination in soil and crop $\mathrm{Zn}$ toxicity. But in general $\mathrm{Zn}$ deficiency is widely realized across the globe,resulting in substantial losses in crop yields and human nutritional health problems. Nearly $25 \%$ of the world's population is at risk due to $\mathrm{Zn}$ deficiency. Zinc deficiency affects about 2.2 billion people world-wide (Prasad, 2012). Many agricultural countries around the world are affected by zinc deficiency (Tuerk and Fazel, 2009). Further it is reported that areas with zinc deficient soils are often regions with widespread zinc deficiency in humans. A basic knowledge of the dynamics of zinc in soils, understanding of the uptake and transport of zinc in crops and characterizing the response of crops to zinc deficiency are essential steps in achieving 
sustainable solutions to the problem of zinc deficiency in crops and humans (Alloway, 2008). Increasing the amount of zinc in the soil and thus in crops and animals/humans is considered as an effective preventative measure. This paper is mainly discusssoil $\mathrm{Zn}$ status of Karnataka and the responses of various horticultural crops to $\mathrm{Zn}$ application for effective management and utilization of $\mathrm{Zn}$ in crop production as well as to mitigate the $\mathrm{Zn}$ deficiency or malnutrition in human/animals.

\section{Physiographic Landforms and Land Use Pattern of Karnataka}

Physiographically, Karnataka is part of well defined regions of India such as the Deccan Plateau, the Western Ghats, and the Coastal Plains. It is located approximately between $11.5-18.5^{\circ} \mathrm{N}$ latitude and 74 $78.5^{\circ} \mathrm{E}$ longitude. The state can be divided into 1 . Coastal zone, 2.Malnad area (Central plateau), 3. Northern maidan 4.Northern dry maidan and 5. Southern Karnataka Plateau. It is land of rivers, waterfalls, plains, hills, peaks and plateau. The main rivers are Cauvery, Hemavati, Tungabhadra, Godavari, Krishna, Palar, North and South Pennar, etc. It has a dynamic weather due to land's altitude, topography and the distance from sea. The climate of Karnataka ranges from arid to semi-arid to humid tropical. South West and North East monsoon bring rainfall to Karnataka and mean annual rainfall is around $1355 \mathrm{~mm}$. It experiences four seasons in a year: Summer (March-May); Monsoon (JuneSeptember); Post-monsoon (October-December); and Winter (January-February). The land use pattern of Karnataka is described in Table 1 and about $55 \%$ of total geographical area is put under cultivation. Mostly rainfed farming is followed in Karnataka and the areasown more than once in a year is very low (only $8 \%$ of cultivated area).

Table 1: The land use pattern of Karnataka

\begin{tabular}{lc}
\hline Land use pattern & $\begin{array}{c}\text { Area } \\
\text { (in m ha) }\end{array}$ \\
\hline Total geographic area & 19.17 \\
Reporting area for land utilization statistics & 19.05 \\
Forest & 3.03 \\
Not available for cultivation & 1.92 \\
Other uncultivated land excluding & 2.13 \\
fallow land &
\end{tabular}

Fallow land

Net area sown

10.40

Area sown more than once

0.84

Total cropped area

11.24

Source: Directorate of Economics and Statistics (2015)

\section{Soils of Karnataka}

Soils of Karnataka are grouped into different major soil orders viz., Alfisols, Aridisols, Entisols, Histosols, Inceptisols, Ultisols and Vertisols (Fig. 1). According

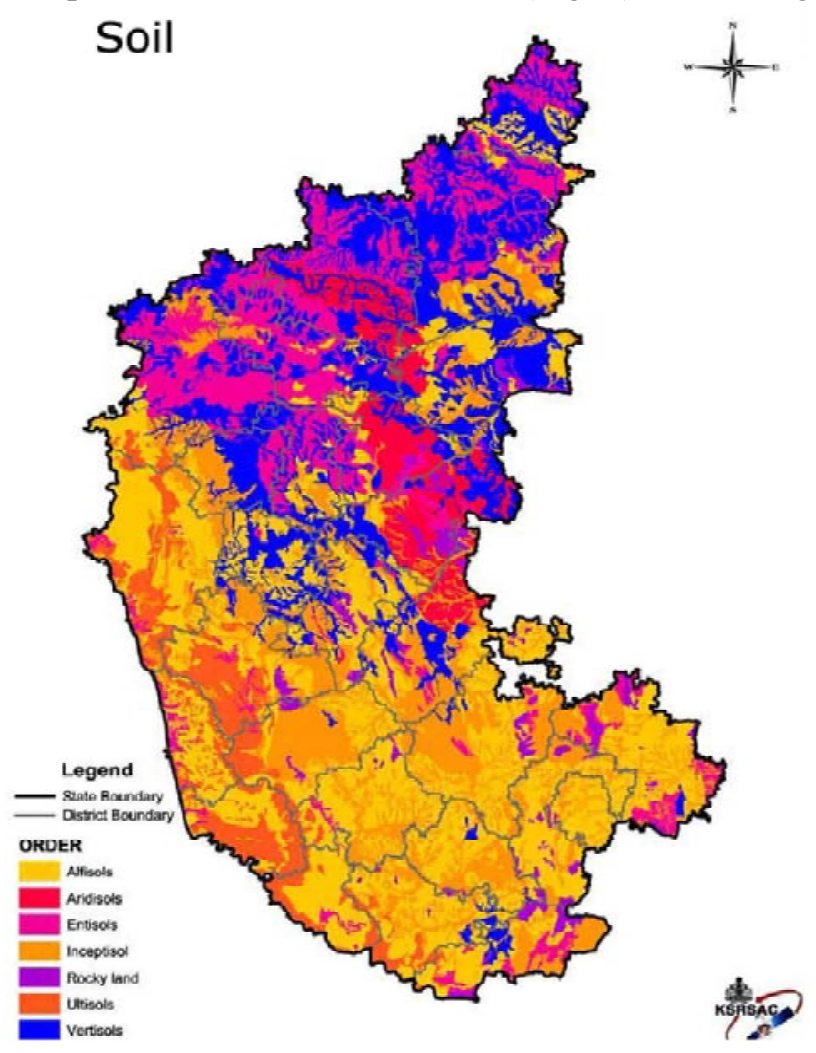

Fig. 1: Major soil orders of Karnataka

to Soil Survey Data, the soils of Karnataka can be divided under nine groups. They are red sandy soils, red loamy soils, shallow black soils, medium black soils, deep black soils, mixed black and red soils, laterite soils, laterite gravelly soils and coastal alluvium. Most of the soils has acidic to neutral to slightly alkaline $\mathrm{pH}$, low-medium organic carbon, medium to high available $\mathrm{N}$ and $\mathrm{K}$, low in available $\mathrm{P}$, deficient in $\mathrm{Zn}$ and sufficient in other micronutrients.

\section{Soil Zn status of Karnataka}

In India, $\mathrm{Zn}$ is now considered as fourth most important yield limiting nutrient after $\mathrm{N}, \mathrm{P}$ and $\mathrm{K}$, 
respectively. Analysis of 256000 soils and 25000 plant samples from all over the India showed that $49 \%$ of the soils and $44 \%$ of the plant samples were potentially $\mathrm{Zn}$ deficient and that this was the most common micronutrient problem affecting crop yields in India (Arunachalam et al. 2013). Deficiency of $\mathrm{Zn}$ has increased in Southern states because of intensive cropping and extensive use of NPK fertilizers without micronutrients. Further it has been reported from periodic assessment of soils that, by the year 2025, $\mathrm{Zn}$ deficient soils in India is likely to increase from 49 to $63 \%$ as most of the marginal soils brought under cultivation are showing Zn deficiency (Singh, 2006). Families consuming the farm produce from $\mathrm{Zn}$ deficient soil leads to low $\mathrm{Zn}$ in their blood plasma compared to those who were fed on produce from regular $\mathrm{Zn}$ supplied soils. Therefore application of $\mathrm{Zn}$ is essential to maintain soil, seeds/crops and blood plasma of humans and animals (Singh, 2009). In view of the emerging $\mathrm{Zn}$ deficiencies in Southern States and micronutrient malnutrition problems in rural population, it is inevitable to study soil $\mathrm{Zn}$ status as well as its response in various horticultural crops.

More than $75 \%$ of the soil samples in Karnataka are found to be deficient in Zn (Fig.2). This might be due to high soil $\mathrm{pH}$, poor organic matter content, excessive removal by crop intensification and faulty management practices like imbalance fertilizer

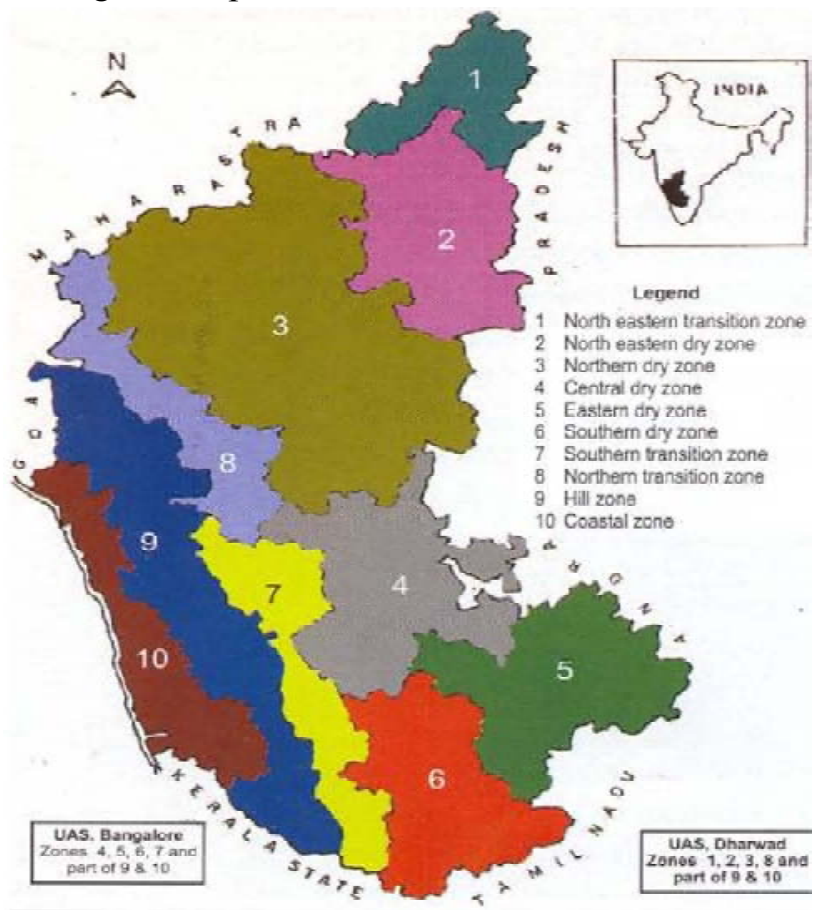

Fig. 2: Agro-ecological zones of Karnataka state management. In traditional areca nut growing soils of Karnataka, the available zinc content of soils ranged from 2.9 to $8.2 \mathrm{mg} / \mathrm{kg}$ with a mean value of $4.17 \mathrm{mg} /$ kg. Similarly Thirthahalli area had $4.7 \mathrm{mg} \mathrm{Zn} \mathrm{kg}^{-1}$ soil; Sagar area had $3.7 \mathrm{mg} \mathrm{Zn} \mathrm{kg}^{-1}$ soil and Sringeri area had $4.7 \mathrm{mg} \mathrm{kg}^{-1}$ soil whereas, zinc status in soils under mulberry (Mysore, Tumkur, Bangalore, Kolar) ranged from 0.40 to $0.69 \mathrm{mg} / \mathrm{kg}$. More than $95 \%$ of the samples analyzed were found to be deficient in zinc and the remaining samples recorded just sufficient zinc status in Malaprabha right bank command area (Ravikumar et al., 2007). Agro-ecological regions of Karnataka and their $\mathrm{Zn}$ status is depicted in Fig. 2 \& 3 (Table 2).

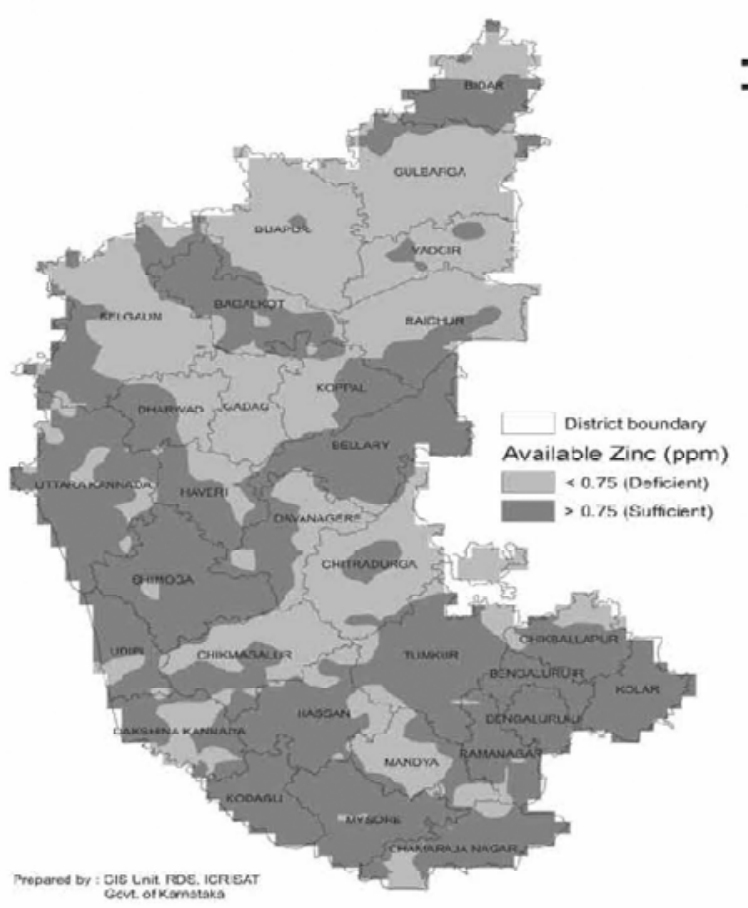

Fig. 3: Soil Zn status of Karnataka

\section{Factors Affecting Zinc Availability in Soils}

The total zinc content of the soils is of little importance in predicting the zinc supplying capacity of a soil. The solubility of zinc in soil is controlled by the matrix of iron, aluminium, manganese and other elemental oxides, carbonates, silicates and organic compounds. Soil reaction, organic matter, type and extent of clay, calcium carbonate, iron and aluminium oxides, and soil phosphorus affect the zinc availability to plants. Let us see some of the major soil factors that affect the $\mathrm{Zn}$ availability in this region. 
Table 2: Response of banana to $\mathrm{Zn}$ an on farm study, Doddaballapur, Karnataka

\begin{tabular}{|l|c|c|c|c|c|c|}
\hline \multirow{2}{*}{$\begin{array}{l}\text { Name of } \\
\text { the Farm }\end{array}$} & \multicolumn{2}{|c|}{ Yield (t/ha) } & \multicolumn{2}{c|}{ Leaf Zn (mg/kg) } & \multicolumn{2}{c|}{ Leaf P (\%) } \\
\hline No Zn Farm & 65.4 & 74.5 & 14.2 & 24 & 1.16 & 0.84 \\
\hline KA Farm & 55.6 & 58.4 & 15.0 & 26 & 0.96 & 0.64 \\
\hline PS Farm & 49.4 & 60.4 & 9.0 & 28 & 0.91 & 0.72 \\
\hline MG Farm & 64.4 & 74.4 & 18.0 & 32 & 0.48 & 0.74 \\
\hline
\end{tabular}

\section{Soil reaction}

The $\mathrm{pH}$ of Karnataka soils are mostly in neutral to slightly alkaline range particularly in Northern, Central and Southern plateau region. Coastal as well as Western Ghats region and its surrounding areas have acidic $\mathrm{pH}$ range (Fig. 4). Availability of zinc decreases

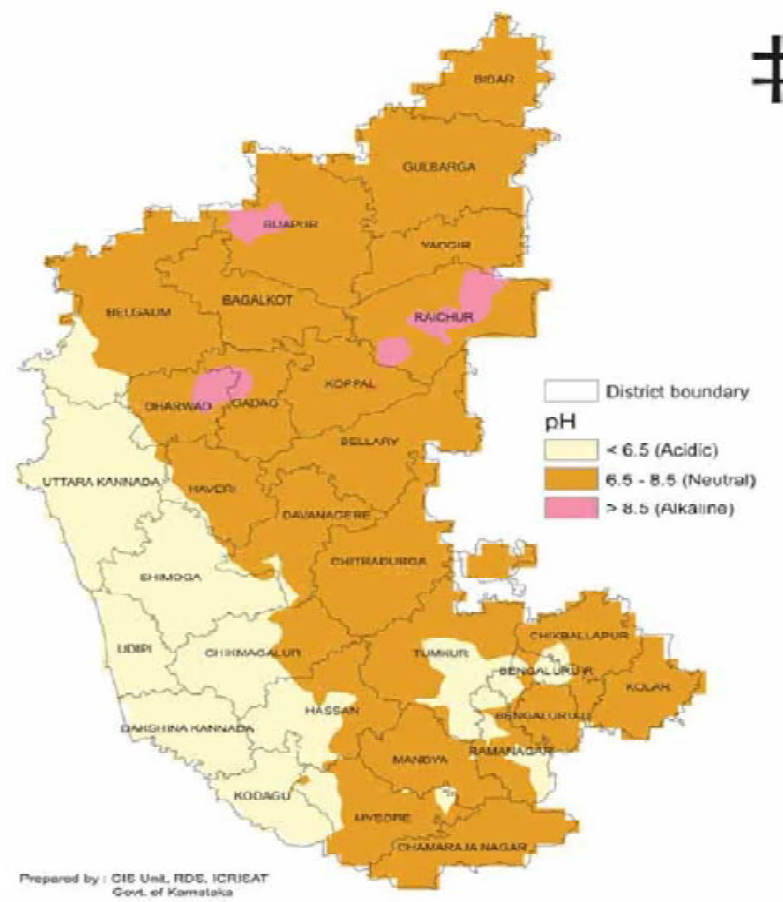

Fig. 4: Soil pH status of Karnataka state

with the increase in soil $\mathrm{pH}$. The solubility of zinc is highly dependent on $\mathrm{pH}$ and decreases by 100 folds for each unit increase in soil $\mathrm{pH}$. The solubility of zinc is maximum in the $\mathrm{pH}$ range of 5 to 7 in the mineral soils and 4.5 to 6.0 in the organic soils. Zinc deficiencies occur usually in soils of $\mathrm{pH} 6.0$ or more. So expected zinc deficiency is mainly in Northern, Central and Southern plateau region. Soil $\mathrm{pH}$ may influence the transport of adsorbed zinc to plant tops.Stability of soluble and insoluble organic complex of zinc depends on soil $\mathrm{pH}$. The reduced availability of zinc with increase in soil $\mathrm{pH}$ was attributed to the formation of zinc hydroxides.

\section{Soil organic matter}

Organic matter status of soils of Karnataka is depicted in Fig. 5. Organic matter can have negative influence

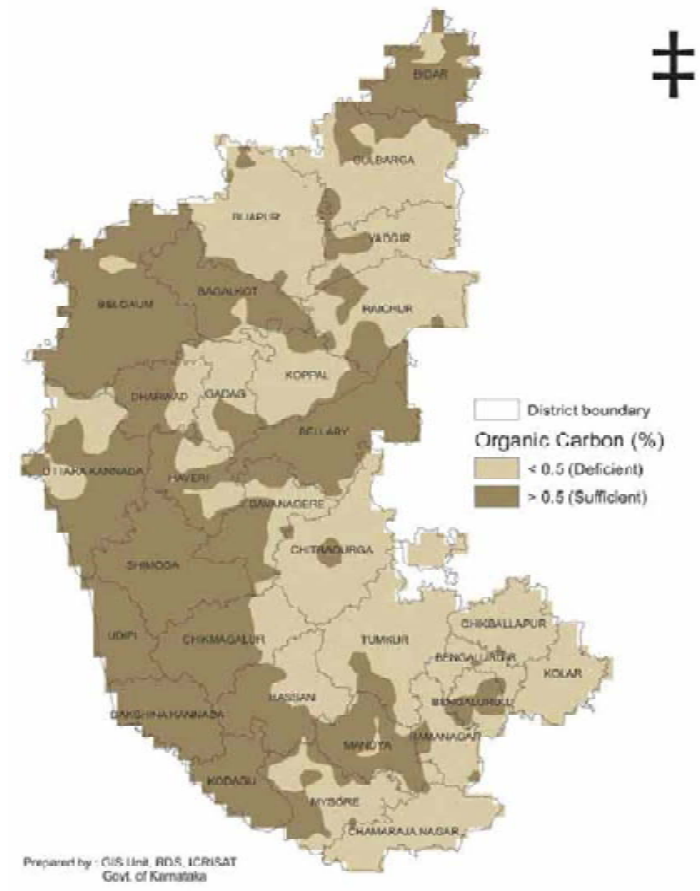

Fig. 5: Spatial distribution of organic carbon in soils of Karnataka

on available zinc in organic matter rich acid soils of coastal Karnataka.The zinc availability increases with increased content of organic matter. Organic matter plays an important role on the availability of zinc through the formation of soluble organo-metal complexes and stable metalo-organic complexes. Metal complex with fulvic acid fraction of organic matter is highly water soluble. Natural complexing agents present in the organic materials effectively enhance concentration of soluble zinc complexes in soil solution through dissolution of sparingly soluble zinc compound and chelation of zinc ions so liberated. 


\section{Soil phosphorus}

The soil $\mathrm{P}$ status of Karnataka is depicted in Fig. 6 . A large area is having either sufficient available $\mathrm{P}$ in

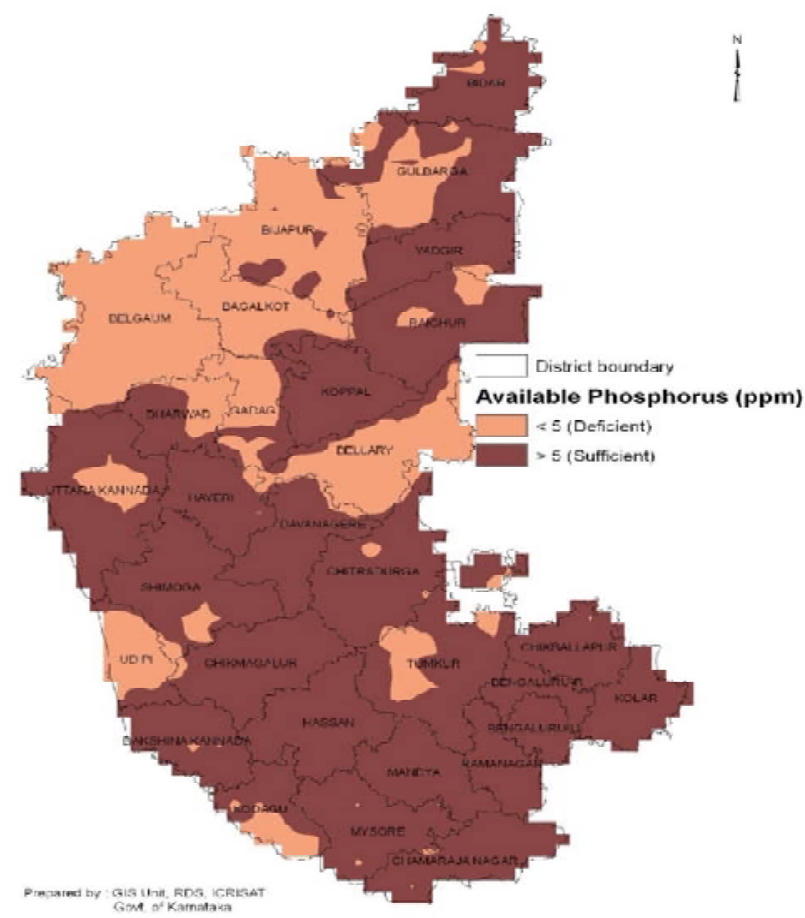

Fig. 6: Soil Phosphorus status of Karnataka

soil or in excess due to accumulations following continuous application of phosphatic fertilizers. Phosphorus induced $\mathrm{Zn}$ disorder in plant is commonly associated with high levels of available $\mathrm{P}$ or with the application of $\mathrm{P}$ to the soil.

\section{Four possible causes of $\mathbf{P}$ induced $\mathrm{Zn}$ deficiency}

(a) slower rate of translocation of $\mathrm{Zn}$ from roots to top

(b) Accentuating $\mathrm{Zn}$ deficiency in plants in presence of high available $P$

(c) Simple dilution effect on $\mathrm{Zn}$ concentration in the top owing to growth response of P. Excess $\mathrm{P}$ interferes with metabolic functions of $\mathrm{Zn}$ within the plant cells. When there is slight or more of yield to $\mathrm{P}$ application, $\mathrm{Zn}$ concentration at the top of the plant and uptake of $\mathrm{Zn}$ reduces

(d) Metabolic disorder with plant cells related to an imbalance between P \& Zn. Green house experiments have shown that the concentration and uptake of $\mathrm{Zn}$ increased in the roots and decreased in the leaves, nodes and internodes of vegetables due to the increased levels of $P$ application. $\mathrm{Zn}$ availability in acid soils of
Karnataka with high available phosphorus $\mathrm{P}$ (30.8 $\mathrm{kg} \mathrm{P}_{2} \mathrm{O}_{5}$ ha $^{-1}$ ) was non-significantly correlated with available $\mathrm{Zn}$.

Considering the above four factors, Karnataka soils having high $\mathrm{P}$ status in major area shows $\mathrm{P}$ induced $\mathrm{Zn}$ deficiency in many crops either in the form of visible symptoms or hidden hunger of varying degree.

\section{Soil Maps as Tools to Delineate and Manage Deficient Regions}

Soil testing can be used to diagnose and manage nutrient problems in the farmers' fields. Typical results from ICRISAT on soil $\mathrm{Zn}$ status for two districts in Karnataka are included here as an example (Fig.7). A large contiguous tract of land deficient in $\mathrm{Zn}$ was identified across Bagepalli and Gudibanda blocks in
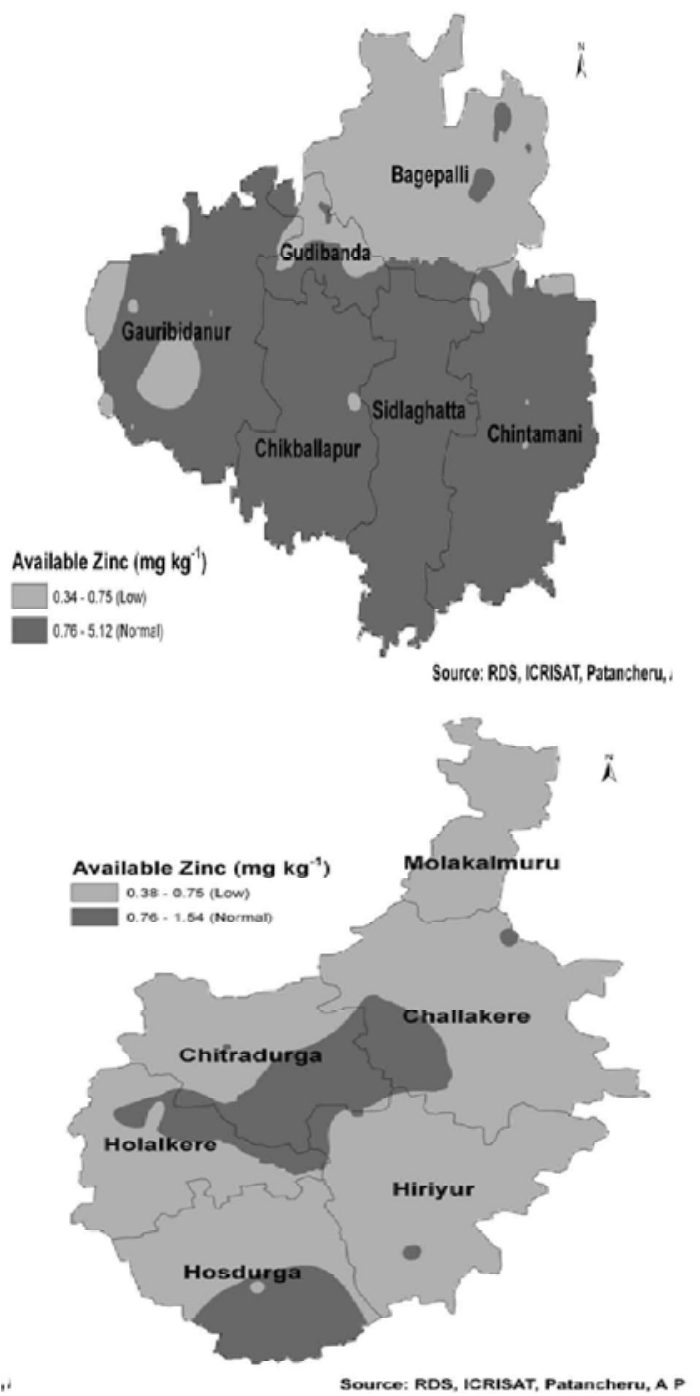

Fig. 7: Block level soil Zn status of Chikballapur and Chitradurga district. 
Table 2 : Status of $\mathrm{Zn}$ in agro-ecological regions of Karnataka

\begin{tabular}{|c|c|c|c|c|}
\hline $\begin{array}{l}\text { Agro- } \\
\text { ecological } \\
\text { region }\end{array}$ & $\begin{array}{c}\text { Districts name (Number } \\
\text { of Taluks) }\end{array}$ & Taluks name & $\begin{array}{l}\text { Zn } \\
\text { status }\end{array}$ & Reference \\
\hline $\begin{array}{l}\text { Southern } \\
\text { transition } \\
\text { zone of } \\
\text { Karnataka }\end{array}$ & $\begin{array}{l}\text { Hassan (4), Chickmagalur } \\
\text { (1), Shimoga (3), Mysore } \\
\text { (3), Davanagere (2). }\end{array}$ & $\begin{array}{l}\text { H.D.Kote, Hunsur, Periyapatna, H.N.Pura, } \\
\text { Alur, Arkalgud, Belur, Tarikere, } \\
\text { Bhadravathi, Shimoga, Honnali, } \\
\text { Shikaripura, Channagiri. }\end{array}$ & $\begin{array}{l}\text { Above } \\
\text { critical } \\
\text { levels* }\end{array}$ & $\begin{array}{l}\text { Ramana et } \\
\text { al. }(2000)\end{array}$ \\
\hline $\begin{array}{l}\text { Coastal agri- } \\
\text { eco zone of } \\
\text { Karnataka }\end{array}$ & $\begin{array}{l}\text { Udupi (3), } \quad \text { D. } \\
\text { Kannada (5), U. Kannada } \\
\text { (5) }\end{array}$ & $\begin{array}{l}\text { Karwar, Kumta, Honnavar, Bhatkal, } \\
\text { Ankola, Bantwal, Udupi, Belthangadi, } \\
\text { Karkala, Kundapura, Mangalore, Puttur, } \\
\text { Sulya. }\end{array}$ & $\begin{array}{l}\text { Much } \\
\text { higher } \\
\text { than the } \\
\text { critical } \\
\text { levels }\end{array}$ & $\begin{array}{l}\text { Gowda et } \\
\text { al. (2001a) }\end{array}$ \\
\hline $\begin{array}{l}\text { Northern dry } \\
\text { and northern } \\
\text { transition } \\
\text { zones of } \\
\text { Karnataka }\end{array}$ & $\begin{array}{l}\text { Koppal (4), Gadag (5), } \\
\text { Belgaum (9), Bijapur (5), } \\
\text { Bagalkot (6), Bellary (7), } \\
\text { Davangere (1), Raichur (2), } \\
\text { Dharwad (4), Haveri (6), }\end{array}$ & $\begin{array}{l}\text { Gangavathi, Koppal, Kushtagi, Lingasugur, } \\
\text { Sindhanur, Yelburga, Badami, Bagalkote, } \\
\text { Bagewadi, Bilgi, Bijapur, Hungund, Indi, } \\
\text { Jamkhandi, Mudhol, Muddebihal, Sindhagi, } \\
\text { Bellary, Hagaribommanahalli, } \\
\text { Harapanahalli, Hadagali, Hospet, Kudligi, } \\
\text { Sandur, Siruguppa, Ron, Navalgund, } \\
\text { Naragund, Gadag, Mundargi, Ramdurga, } \\
\text { Gokak, Raibag, Soundatti, Athani, Hukkeri, } \\
\text { Chikodi, Bailhongal, Belgaum, Haveri, } \\
\text { Shiggaon, Shirahatti, Kundagol, Savanur, } \\
\text { Hubli, Dharwad, Byadgi, Hirekerur, } \\
\text { Raneebennur. }\end{array}$ & $\begin{array}{l}\text { Well } \\
\text { above } \\
\text { the } \\
\text { critical } \\
\text { levels }\end{array}$ & $\begin{array}{l}\text { Ramana et } \\
\text { al. (2000) }\end{array}$ \\
\hline $\begin{array}{l}\text { Eastern and } \\
\text { southern dry } \\
\text { zones of } \\
\text { Karnataka }\end{array}$ & $\begin{array}{l}\text { Bangalore Rural (4), } \\
\text { Ramanagar (4) Bangalore } \\
\text { Urban (3), Kolar (5), } \\
\text { Chikkaballpur (6) Tumkur } \\
\text { (2). } \\
\text { Mysore (4), } \\
\text { Chamarajnagar(4), Mandya } \\
\text { (7), Tumkur (2), Hassan } \\
\text { (2). }\end{array}$ & $\begin{array}{l}\text { Gubbi, Tumkur, Anekal, Bangalore South, } \\
\text { Bangalore North, Channapatna, } \\
\text { Devanahalli, Doddabalapur, Hosakote, } \\
\text { Kankapura, Magadi, Nelmangala, } \\
\text { Ramanagar, Bagepalli, Bangarpet, } \\
\text { Chikkabalapur, Chintamani, Gudibanda, } \\
\text { Gowribidanur, Kolar, Malur, Mulbagal, } \\
\text { Sidalaghatta, Srinivasapura, K.R.Nagar, } \\
\text { T.Narasipur, Mysore, Kollegal, Nanjangud, } \\
\text { Turuvekere, Kunigal, Nagamangala, } \\
\text { Srirangapatna, Malavalli, Maddur, Mandya, } \\
\text { Pandavapura, K.R.Pet, Channarayapatna, } \\
\text { Hassan, Chamarajanagar, Yelandur, } \\
\text { Gundlupet. }\end{array}$ & $\begin{array}{l}\text { Above } \\
\text { the } \\
\text { critical } \\
\text { level }\end{array}$ & $\begin{array}{l}\text { Gowda et } \\
\text { al. }(2001 b)\end{array}$ \\
\hline $\begin{array}{l}\text { North east } \\
\text { transition } \\
\text { and dry } \\
\text { zones of } \\
\text { Karnataka }\end{array}$ & $\begin{array}{l}\text { Bidar (5), Gulbarga (2), } \\
\text { Gulbarga (5), Yadgir (3) } \\
\text { \&Raichur (3) }\end{array}$ & $\begin{array}{l}\text { Aland, Bhalki, Basvakalyan, Bidar, } \\
\text { Chincholi, Humnabad, Aurad, Afzalpur, } \\
\text { Chitapur, Gulbarga, Jewargi, Sedum, } \\
\text { Shahapur, Yadgir, Shorapur, Raichur, } \\
\text { Deodurga, Manvi. }\end{array}$ & $\begin{array}{l}\text { Below } \\
\text { the } \\
\text { critical } \\
\text { levels }\end{array}$ & $\begin{array}{l}\text { Ramana et } \\
\text { al. (2001b) }\end{array}$ \\
\hline $\begin{array}{l}\text { Hilly and } \\
\text { central dry } \\
\text { zones of } \\
\text { Karnataka }\end{array}$ & $\begin{array}{l}\text { U.Kannada (6), Belgaum } \\
\text { (1), Dharwad (1), Haveri } \\
\text { (1), Shimoga (4), } \\
\text { Chickmangalur (6), } \\
\text { Kodagu (3), Hassan (2), } \\
\text { Chitradurga (6), } \\
\text { Davangere (3), Tumkur } \\
\text { (6) }\end{array}$ & $\begin{array}{l}\text { Sirsi, Siddapura, Yellapura, Supa, Haliyal, } \\
\text { Mundgod, Khanapur, Soraba, Hosanagar, } \\
\text { Sagar, Thirthahalli, Koppa, Sringeri, } \\
\text { Mudigere, Narasimharajapur, } \\
\text { Chickmagalur, Kalaghatagi, Hangal, } \\
\text { Sakleshpur, Virajpet, Somwarpet, Madikere, } \\
\text { Challakere, Chitradurga, Davanagere, } \\
\text { Harihara, Hiriyur, Hosadurga, Holalkere, } \\
\text { Jagalur, Molkalmuru, Arasikere, Kadur, } \\
\text { Madhugiri, Pavagada, Koratagere, } \\
\text { C.N.Halli, Sira, Tiptur. }\end{array}$ & $\begin{array}{l}\text { Below } \\
\text { the } \\
\text { critical } \\
\text { range }\end{array}$ & $\begin{array}{l}\text { Gowda et } \\
\text { al. (2002) }\end{array}$ \\
\hline \multicolumn{5}{|c|}{${ }^{*}$ Critical level of zinc in soil $0.75 \mathrm{mg} \mathrm{kg}^{-1}$} \\
\hline
\end{tabular}


Chikballapur district. Other blocks viz. Gauribidanur and Chintamani in Chikballapur district also had pockets potentially deficient in $\mathrm{Zn}$. The results also showed that almost all blocks in Chitradurga district were critically deficient in Zn (Fig.7)

\section{Response of Horticultural Crops to Applied Zn}

Zinc is applied to crop by soil application, foliar spray, coating/soaking of seeds or seedling in $\mathrm{Zn}$ solution or slurry. Among these methods, soil and foliar application is generally practiced (Ganeshamurthy et al., 2015). The optimum micronutrient content of plant tissues of various horticultural crops is depicted (Raghupathi et al. 2014). In case of $\mathrm{Zn}$, optimum range in most of the fruit crops is $20-50 \mathrm{ppm}$. Further, the response of crops to $\mathrm{Zn}$ application is reported by many workers across the country. In the following paragraphs, the response of $\mathrm{Zn}$ along with other micronutrient in many horticultural crops studied in the region is briefly elaborated.

Zinc and Boron deficiency are the most important micronutrient disorders in horticultural crops. Foliar spray of $0.15 \%$ zinc corrects the deficiency (Ganeshamurthy et al., 2013). Studies in sweet orange have indicated that soil application of zinc sulphate at $1 \mathrm{~kg} /$ plant once in every 4 years is the most effective method for controlling $\mathrm{Zn}$ deficiency in neutral and alkaline soils. Foliar spray with zinc sulphate $(0.3 \%)$ along with humectant $\left(\mathrm{CaCl}_{2}\right.$ at $\left.2 \%\right)$ once in a year during the active flush period is equally effective.

\section{Effect of $\mathrm{Zn}$ application in vegetable crops}

Zinc fertilizer application can increase yield from 15 to $25 \%$ in French bean, capsicum, chili, onion, tomato and cabbage. Screening of a number of tomato varieties for their tolerance to low zinc in the soil indicated that varieties with semi-determinate growth habits like 'Arka Saurabh', 'Arka Vikas' and some $\mathrm{F}_{1}$ hybrids are least tolerant, whereas those with determinate growth like 'Sioux' and 'Pusa Ruby' are more tolerant and IIHR selection 1098 was the most tolerant. Tolerant varieties obtained adequate zinc from the soil with the help of more fibrous roots and lowering the $\mathrm{pH}$ of the rhizosphere. Combined application of B, Zn,Cu, Fe, Mn@100 ppm and Mo @ 50ppm produced the highest tomato fruit yield of $26.7 \mathrm{tha}^{-1}$ compared to the yield of 24.0 tobtained with $\mathrm{Zn}$ and $20.0 \mathrm{t} \mathrm{ha}^{-1}$ in control (Bhatt et al., 2004). In cabbage, activity of enzyme carbonic anhydrase was found to be a good index of metabolically active zinc. Foliar application of $0.5 \% \mathrm{ZnSO}_{4}$ recorded minimum mean weight loss $(20.16 \%)$ of cabbage heads (Sarma et al., 2005). Application of $20 \mathrm{~kg} \mathrm{ZnSO}_{4} \mathrm{ha}^{-1}$ to cauliflower cultivar Snowball-16 produced the highest marketable curd yield. Performance of the applied Znwas distinctly superior when applied in conjunction of $22 \mathrm{~kg} \mathrm{Pha}^{-1}$. Application of $8 \mathrm{~kg} \mathrm{Zn} \mathrm{ha}^{-1}$ gave16\% higher yield of potato than control and 4.5\% higher than foliar sprays @ $1 \mathrm{~kg} \mathrm{ha}^{-1}$ (Raghav and Singh, 2004). Foliar spray of $1 \% \mathrm{ZnSO}_{4}$ to onion produced highest seed yield per plant andunit area with high germination percentage (Khalate et al., 2002), indicating the usefulness of the $\mathrm{Zn}$ in improving the seed health. Foliar sprayof $\mathrm{ZnSO}_{4} @ 0.75 \%$ to 'Pudukottailocal'cucumber produced maximumfruit set, number of fruit/vine, fruit weight and yield (Madhu sudhan and Shakila, 2003). In okra, combined spray of $\mathrm{Zn}$ and Mo (20 ppm each) gave highestpod yield of $6.9 \mathrm{t} \mathrm{ha}^{-1}$ compared to $2.8 \mathrm{t}$ in control (Srihari et al., 1987).Significantly higher okra yield of $5.5 \mathrm{tha}^{-1}$ was obtained when $40 \mathrm{~kg} \mathrm{ZnSO}_{4}$ ha $^{-1}$ was applied as basal soil applicationas compared to $4.1 \mathrm{tha}^{-1}$ obtained with $2.5 \mathrm{~kg} \mathrm{ZnSO}_{4} \mathrm{ha}^{-1}$ dose appliedto foliage twice and control (Raghavand Sharma, 2003).

\section{Effect of $\mathrm{Zn}$ application in Mango}

From the results of two years data on application of $\mathrm{Zn}$ to Dashehari mango, it is observed that $\mathrm{Zn}$ application had increased the mango yield and other quality parameters such as TSS, ascorbic acid and sugar: acid ratio (Singh et al., 2003). Application of $\mathrm{Zn}$ increased the mango yield by $21 \%$ and fruit quality also enhanced. These parameters are further improved when $\mathrm{Zn}$ was applied with other micronutrients ( $\mathrm{B}$ and $\mathrm{Cu}$ ).

\section{Influence of $\mathrm{Zn}$ on Banana Yield, Leaf $\mathrm{Zn}$ and $\mathrm{P}$}

On farm studies conducted in four different farms of Doddaballapur, Karnataka revealed that foliar spray of $\mathrm{Zn}$ at $0.25 \%$ at regular interval had tremendously increased the banana yield (at the scale of 5.01$22.26 \%$ ) and leaf $\mathrm{Zn}$ content and reduced the leaf $\mathrm{P}$ content in the most cases when compared to the control treatment (where no $\mathrm{Zn}$ is applied). It showed that application of $\mathrm{Zn}$ is very useful to the crop growth and development and to attain higher yield. 


\section{Response of mandarin orange to $\mathrm{Zn}$ application}

The effect of $\mathrm{Zn}$ and other micronutrients on yield and quality of mandarin orange has been reported by Saraswathy et al. (1998) and Dineshbabu and Yadav (2005).Application of $\mathrm{Zn}$ along with urea and other micronutrients boosted the number of fruits per tree, fruit weight and yield. In addition, it enhanced fruit juice content, TSS, titratable acidity, total sugars and ascorbic acid content of mandarin orange.

\section{Zinc application on growth and yield of papaya}

Papaya showed clear-cut response to $\mathrm{Zn}$ and other micronutrients ( $\mathrm{Fe}$ and $\mathrm{B}$ ) application (Pant and Lavania, 1998). Application of $\mathrm{ZnSO}_{4}(0.15 \%)$ through foliar spray improved the number of fruits per plant and fruit yield. Moreover, application of $\mathrm{Zn}$ along with other micronutrients further enhanced the plant growth and yield of papaya.

\section{Effect of application of $\mathrm{Zn}$ and $B$ on Sapota}

Soil application of $\mathrm{ZnSO}_{4}(50 \mathrm{~g} /$ tree$)$ has increased fruit weight and number of fruits per tree and yield of sapota. Increasing the amount of $\mathrm{ZnSO}_{4}$ from 50$100 \mathrm{mg}$ did not show any significant improvement in these parameters. Application of $\mathrm{ZnSO}_{4}(50 \mathrm{~g})$ along with $25 \mathrm{~g}$ borax per tree had further improved fruit weight and number of fruits per tree and yield of sapota and which are at par with that of $\mathrm{ZnSO}_{4}(100$ g) + borax (50 g) per tree (Saraswathy et al. 2004). Moreover, the highest yield and fruit weight and numbers has been observed in plants that received $\mathrm{ZnSO}_{4}(50 \mathrm{~g})+$ borax $(25 \mathrm{~g})$ per tree $+0.5 \% \mathrm{ZnSO}_{4}$ spray. From the study, it was clear that the combined practices of both soil and foliar application of $\mathrm{Zn}$ is more beneficial to plant than any single practices.

\section{Effect of $\mathrm{Zn}$ and $\mathrm{B}$ on Pineapple}

Application of $\mathrm{ZnSO}_{4}$ alone and in combination with borax influenced fruit weight and quality parameters of in 'Giant Kew' pineapple. When compared among different levels of $\mathrm{ZnSO}_{4}$ application (0.2, 0.4 and $0.6 \%$ foliar spray), though $0.6 \% \mathrm{ZnSO}_{4}$ spray was found to be superior, application of $0.4 \% \mathrm{ZnSO}_{4}$ spray is effective and economical (Kar et al. 2012). Further combined application of borax $(0.05 \%)$ along with $\mathrm{ZnSO}_{4}$ did not show any significant change in these parameters.

\section{Influence of Foliar Spray of $\mathrm{ZnSO}_{4}$ on Grapes}

Under field trials, foliar application of $\mathrm{ZnSO}_{4} @ 0.4 \%$ in 5-year old 'Perlette' grape vines was the most effective in increasing yield, bunch weight and berry weight and quality parameters (Dhillon and Bindra, 1995).

\section{Effect of Zn Application in Guava}

In 7-year old 'Allahabad Safeda' guava, application of foliar spray of $0.6 \% \mathrm{ZnSO}_{4}$ produced significantly higher yield and quality of fruits. Application of zinc caused $72 \%$ fruit set against $64 \%$ in control, $166 \mathrm{~g}$ fruit weight against 143g in control, 499 fruits/tree against 426 in control, $82 \mathrm{~kg}$ fruit yield against $60 \mathrm{~kg} /$ tree in control, $11.3 \%$ TSS against $9.6 \%$ in control, $0.36 \%$ acidity against 0.43 in control, and $127 \mathrm{mg}$ ascorbic acid against $103 \mathrm{mg}$ in control. Bronzing', a common disorder in guava occurring on the red soils of poor fertility in Karnataka was found to be caused due to combined deficiencies of phosphorus, potassium and zinc. Severe cases of disorder result in trunk splitting. Foliar spray with DAP $(0.5 \%)$, potassium sulphate $(0.5 \%)$ andzinc sulphate $(0.3 \%)$ controls the disorder. Zinc deficiency alone can be effectively controlled by soil application of zinc sulphate @ 800 $\mathrm{g} /$ plant once in 4 years in guava.

\section{CONCLUSIONS}

Wide spread Zn deficiency is a reality in soils of Karnataka and is equally distributed in all the agroclimatic regions of the state. District level deficiency maps helps to a great extent in management of $\mathrm{Zn}$ deficiency in soils and crops. Horticultural crops respond very significantly to $\mathrm{Zn}$ application. Further, the response and amount of $\mathrm{Zn}$ required by individual crops vary and it is influenced by climate and soil factors. Many site-specific nutrient management studies need to be done for effective management of $\mathrm{Zn}$. From the available data, it is obvious that application of $\mathrm{Zn}$ to horticultural crops enhances the $\mathrm{Zn}$ content of the produce. This helps in enhancing the availability of $\mathrm{Zn}$ in the food.

\section{AKNOWLEDGEMENT}

The authors thank ICAR-NBSSLUP and other sources referred in the text for the information used in the review. 


\section{REFERENCES}

Alloway, B.J. 1995. Heavy metals in soils. Blackie Academic and Professional, London.

Alloway, B.J. 2008. Zinc in Soils and Crop Nutrition. International Fertilizer Industry Association, and International Zinc Association, Brussels, Belgium.

Arunachalam, P., Kannan, P., Prabukumar G. and Govindaraj, M. 2013. Zinc deficiency in Indian soils with special focus to enrich zinc in peanut. African Journal of Agricultural Research. 8: 6681-6688.

Bhatt, L., Srivastava, B.K. and Singh,M.K. 2004. Studies on the effect offoliar application of micronutrients ongrowth, yield and economics oftomato (Lycopersiconesculentus Mill.). Progressive Horticulture 36, 331-334.

Cousins, R.J. 1996. Zinc. In Present Knowledge in Nutrition (L.J. Filer and E.E.Ziegler, Eds.), pp. 293-306. International Life Science Institute-Nutrition Foundation, Washington, DC.

Dhillon, W.S. and Bindra, A.S. 1995. Effect of micronutrient sprays on theyield and quality of 'Perlette' grapes. Indian Journal of Horticulture 52, 27-30.

Dhinesh Babu, K. and Yadav, D.S. 2005. Foliar spray of micronutrientsfor yield and quality improvement in Khasi mandarin (Citrus reticulate Blanco). Indian Journal of Horticulture 62,280-281.

Directorate of Economics and Statistics, 2015. Economic Survey of Karnataka 2014-15. Government of Karnataka

Friedland, A.J. 1990. The movement of metals through soils and ecosystems. In Heavy Metal Tolerance in Plants: Evolutionary Aspects (A.J. Shaw, Ed.) pp. 7-19. CRC, Boca Raton, FL.

Ganeshamurthy, A.N., Kalaivanan, D. and Manjunath, B.L. 2017. Nutrients removed from the soil decide the nutritional security of a nation: thecase of iron and zinc in India. Current Science 113(6): 1167-1173.

Ganeshamurthy, A.N., Kalaivanan, D., Selvakumar, G. and Panneerselvam, P. 2015. Nutrient management in horticultural crops. Indian Journal of Fertilizers 11(12): 30-42.

Ganeshamurthy, A.N., Kotur, S.C., Raghupathi, H.B., Satisha, G.C. andVaralakshmi, L.R. 2013. Fertiliser bestmanagement practices in fruit crops. Indian Journal of Fertilisers 9(4): 138-148.

Gowda, N.K.S., Prasad, C.S., Ramana, J.V. and Shivaramaiah, M.T. 2001a. Mineral status of soils, feeds, fodders and animals in coastal agri-eco zone of karnataka.Animal Nutrition and Feed Technology 1, 97-104.

Gowda, N.K.S., Prasad C.S., Ramana, J.V., Ramachandra, K.S. 2001b.Micronutrient profile in soil, feed, fodders and blood samples of animals in eastern and southern dry zones of Karnataka.Indian Journal of Animal Sciences 71 (2): 150-154.

Gowda, N.K.S., Prasad, C.S.,Ramana, J.V. and Shivaramaiah, M.T. 2002. Assessment of mineral status in hilly and central dry zones of Karnataka and ways to supplement them. Indian Journal of Animal Sciences 72(2): 165-170.

IIHR Annual Report. 1997. Indian Institute of Horticultural Research, Hesaraghatta Lake Post, Bengaluru - 560089.

IIPS. 2007.National Family Health Survey 20052006. International Institute of Population Science, Mumbai.

Kar, P.L., Sema, A., Maiti, C.S. and Singh, A.K. 2002. Effect of $\mathrm{Zn}$ and B onfruit and quality traits in pineapple (AnanascomosusL.) South Indian Horticulture 50: 44-48. 
Khalate, S.P., Sanghavi, K.V. and Kadam, J.R. 2002. Effect of somemicronutrients on seed yield and quality of onion cv. Basvant-780). South Indian Horticulture 50: 248-250.

Klug, A. 1999. Zinc finger peptides for the regulation of gene expression. Journal of Molecular Biology 293: 215-218.

Lonnerdal, I.B. 2000. Dietary factors influencing zinc absorption. Journal of Nutrition 130: 13781387.

Madhu Sudhan, P.N. and Shakila, A. 2003. Effect of zinc on growth, flowering and yield of cucumber (Cucumis sativusL.). South Indian Horticulture 51:195-198.

Micronutrient Initiative. 2007. Controlling Vitamins and Mineral Deficiency in India, Meeting the Goal.

NIN.2010. Nutrient requirements and recommended dietary allowances for Indians. A Report of the Expert Group of Indian Council of Medical Research, National Institute of Nutrition, ICMR, Hyderabad.

NIN. 2002.National Nutrition Monitoring Bureau report. National Institute of Nutrition, Hyderabad.

Pant, V. and Lavania, M.L. 1998.Effectof foliar sprays of iron, zinc and boronon growth and yield of papaya (Caricapapaya L.).South Indian Horticulture 46: 5-8.

Prasad, A.S. 2012.Discovery of human zinc deficiency: 50 years later. Journal of Trace Elements in Medicine and Biology 26: 6669.

Raghav, M. and Sharma, R.D. 2003.Growth and yield in tomato-okravegetablepea cropping sequence asaffected by levels and methods of zincapplication. Progressive Horticulture 35: 96-99.

Raghav, M. and Singh, N.P. 2004. Effectof zinc application on growth andyield of potato. Progressive Horticulture 36: 135-137.

Raghupathi, H.B., Ganeshamurthy, A.N. and Ravishankar, H. 2014.Comparison of DRIS ratio norms of selected fruit crops.Indian Journal of Horticulture, 71(2): 168-175.

Ramana, J.V., Prasad, C.S. and Gowda, N.K.S. 2000. Mineral profile of soil, feeds, fodders and blood plasma in southern transition zone of Karnataka. Indian Journal of Animal Nutrition 17(3): 179 - 183.

Ramana, J.V., Prasad, C.S., Gowda, N.K.S. and Ramachandra, K.S. 2001a. Mineral status of soil, feed fodder and blood plasma of animals in Northern dry and Northern transition zones of Karnataka. Indian Journal of Dairy Sciences 54(1): 40-46.

Ramana, J.V., Prasad, C.S., Gowda, N.K.S. and Ramachandra, K.S. 2001b. Levels of MicroNutrients in soil, feed, fodder and animals of North East transition and dry zones of Karnataka. Indian Journal of Animal Nutrition 18(3) : 235 - 242.

Rathore, N., Mishra, N.K., Lal, R.L. and Mishra, D.S. 2009. Effect of foliarapplication of nutrients on yield andquality of litchi cv. Rose Scented. Indian Journal of Horticulture 66: 524-525.

Ravikumar, M.A., Patil, P.L. and Dasog, G.S. 2007. Mapping of nutrients status under 48A distributary in Malaprabha Right Bank Command of Karnataka by Geographic Information System Technique-II: Micronutrients.Karnataka Journal of Agricultural Sciences 20(4): 738-740.

Saraswathy, T., Thangaraj, T., Azhaklamanavalan, R.S. and Balakrishnamurthy, G. 1998. Effect of micronutrients on yield and quality of mandarin orange (Citrus reticulate Blanco).South Indian Horticulture 46 : 128-131.

Saraswathy, S., Balakrishnan, K., Anbu, S., Azhakiamanavalan, R.S. and Thangaraj, T. 2004. Effect of zincand boron on growth, yield andquality of sapota (Manilkara acharas Mill.) cv. PKM-1. South Indian Horticulture 52: 41-44. 
Sarma, P., Goswami, R.K. and Deka, B.C. 2005. Effect of foliar applicationof micronutrients on shelf-life ofcabbage. Indian Journal of Horticulture 62: 160-162.

Singh, M.V. 2006. Micronutrients in crops and in soils of India. InMicronutrients for Global Crop Production: (B.J. Alloway, Ed.). Springer. Business.

Singh, M.V. 2009. Micro nutritional problem in soils of India andimprovement for human and animal health. Indian Journal of Fertilizers 5(4);11-16.
Singh, Y.P., Tiwari, J.P and Misra, K.K.2003. Effect of micronutrients on fruityield and physicochemical characteristics of mango cv. Dashehari. Progressive Horticulture 35: 34-37.

Srihari, D., Singh, B.P. and Rao, D.V.R. 1987. Effect of zinc and molybdenum on growth and yieldof okra [Abelmoschus esculentus (L.) Moench.] cv. Pusa Savani. Progressive Horticulture 19: 31-34.

Tuerk, M.J. and Fazel, N.2009. Zinc deficiency. Current Opinion in Gastroenterology, 25(2), 136-143.

(Received on 21.5.2018 and accepted on 12.12.2019) 